Article

\title{
One-step synthesis of Pt@ZIF-8 catalyst for the selective hydrogenation of 1,4-butynediol to 1,4-butenediol
}

\author{
Chuang Li a, Mingming Zhang a , Xin Di a, Dongdong Yin a, Wenzhen Li ${ }^{\text {b }}$, Changhai Liang a,* \\ a Laboratory of Advanced Materials and Catalytic Engineering, School of Chemical Engineering, Dalian University of Technology, Dalian 116024, Liaoning, \\ China \\ ${ }^{\mathrm{b}}$ DCBE, Biorenewables Research Laboratory, Iowa State University, Iowa 50011, USA
}

\section{A R T I C L E I N F O}

\section{Article history:}

Received 6 May 2016

Accepted 30 June 2016

Published 5 September 2016

\section{Keywords:}

Platinum sol

ZIF-8

One-step synthesis

1,4-Butynediol

Selective hydrogenation

\begin{abstract}
A B S T R A C T
A catalyst consisting of platinum nanoparticles on a ZIF-8 support (Pt@ZIF-8) was synthesized in a straightforward one-step procedure, by adding a nanostructured platinum sol during the formation of ZIF-8 at room temperature. Pt@ZIF-8 was highly porous and well crystallized. The Pt nanoparticles were well dispersed within the ZIF-8 support. In the hydrogenation of 1,4-butynediol, Pt@ZIF-8 exhibited high activity, excellent selectivity for 1,4-butenediol of greater than $94 \%$, and reusability. The Pt@ZIF-8 catalyst did not require further additives. The favorable catalytic performance was attributed primarily to the modification of the ZIF-8 support by the platinum nanoparticles.
\end{abstract}

(C) 2016, Dalian Institute of Chemical Physics, Chinese Academy of Sciences. Published by Elsevier B.V. All rights reserved.

\section{Introduction}

The selective hydrogenation of carbon-carbon triple bonds to double bonds is an important process in the fine chemicals industry, and is relevant to commodities and other specialty chemicals production [1,2]. The partial hydrogenation of 1,4-butynediol (BYD) to 1,4-butenediol (BED) is especially important, because BED is an important intermediate for producing endosulfan [3], vitamins A and B6, and is used in the synthesis of $n$-methyl pyrrolidone [4]. BED is also used as an additive in resin manufacturing [5]. Lindlar catalysts [6] (Pd supported on $\mathrm{CaCO}_{3}$ with a secondary doping of lead) are typical selective supported metal catalysts for the liquid phase hydrogenation of BYD. In these catalysts, lead is used as a dopant to promote the selective reduction of BYD to BED. A basic compound such as quinoline is also added during the reaction, to reduce the rate of the subsequent hydrogenation of BED to 1,4-butanediol (BDO) [1]. The outstanding selectivity of Lindlar catalysts results from the synergistic effect of the lead compounds and other soluble additives. Various Pd and Ni-based catalysts can also be used in this reaction, but require combining with one or more mixed compounds of $\mathrm{Cu}, \mathrm{Zn}, \mathrm{Ca}, \mathrm{Cd}$, and $\mathrm{Ga}$, and/or an organic base [7-9]. The conversion of BYD is significantly lower using these catalyst combinations, and toxic compounds are generally required to obtain high purity products [10]. Developing alternative reusable catalysts for a more sustainable transformation is therefore of interest.

Metal-organic frameworks (MOFs) have attracted much recent attention in the field of heterogeneous catalysis [11-14]. The high surface area, narrow pore diameter, and specific composition of MOFs can yield nanoparticles (NPs) with a uniform size distribution and interesting catalytic activity and

\footnotetext{
* Corresponding author. Tel/Fax: +86-411-84986353; E-mail: changhai@dlut.edu.cn

This work was supported by the National Natural Science Foundation of China (21573031 and 21428301) and the Fundamental Research Funds for the Central Universities (DUT15ZD106 and DUT15RC(4)09).

DOI: 10.1016/S1872-2067(16)62497-X | http://www.sciencedirect.com/science/journal/18722067 | Chin. J. Catal., Vol. 37, No. 9, September 2016
} 
selectivity [15-17]. MOF catalysts with nitrogen-containing groups have been investigated for tailoring the acidity/basicity, solubility/dispersibility, surface area, and selectivity toward the target products in hydrogenation reactions $[18,19]$. In our previous work, a polyvinyl-pyrrolidone (PVP)-protected Pd nano-sol supported on ZIF-8 was shown to be a highly active and selective catalyst for the hydrogenation of BYD [20].

Herein, an acetate-protected Pt nano-sol with a uniform particle size distribution of 1-2 $\mathrm{nm}$ was added during the synthesis of ZIF-8 at room temperature. The obtained Pt@ZIF-8 catalyst was used in the hydrogenation of BYD. We investigated the activity, selectivity, and recyclability of Pt@ZIF-8, and the specific role of ZIF-8 in this reaction.

\section{Experimental}

\subsection{Preparation of Pt nano-sol and synthesis of Pt@ZIF-8}

The Pt NP colloid was prepared through the chemical reduction of $\mathrm{H}_{2} \mathrm{PtCl}_{6} \cdot 6 \mathrm{H}_{2} \mathrm{O}$ by ethylene glycol in the presence of $\mathrm{CH}_{3} \mathrm{COONa}$ as a stabilizer, at $160{ }^{\circ} \mathrm{C}$ for $3 \mathrm{~h}[21,22]$. Then, 11.35 $\mathrm{g}$ of 2-methy imidazole and $12 \mathrm{~mL}$ of the as-prepared Pt colloid ethanol solution were dissolved in $40 \mathrm{~mL}$ of $\mathrm{H}_{2} \mathrm{O}$. An aqueous solution of $\mathrm{Zn}\left(\mathrm{NO}_{3}\right)_{2} \cdot 6 \mathrm{H}_{2} \mathrm{O}(4 \mathrm{~mL})$ was then added under stirring. The mixture was stirred for a further $1.5 \mathrm{~h}$ at $25^{\circ} \mathrm{C}$, after which the black powder was collected by centrifugation. The product was washed twice with $\mathrm{H}_{2} \mathrm{O}$ and then twice with methanol. Drying under vacuum at $120^{\circ} \mathrm{C}$ for $12 \mathrm{~h}$ yielded the 1.0 wt\% Pt@ZIF-8 catalyst. The Pt loading could be controlled by adjusting the amount of Pt colloid added during the synthesis. The precise Pt content as determined by inductively coupled plasma atomic emission spectroscopy (ICP-AES) was 0.98 wt\%. Fig. 1 shows the procedure for preparing Pt@ZIF-8.

\subsection{Characterization}

Powder X-ray diffraction (XRD) patterns were recorded using a D/MAX 2400 diffractometer with monochromatic $\mathrm{Cu} K_{\alpha}$ radiation $(\lambda=0.15418 \mathrm{~nm})$, operated at $40 \mathrm{kV}$ and $100 \mathrm{~mA}$. The surface area, pore volume, and pore size distribution of the ZIF-8 support and Pt@ZIF-8 catalyst were determined from $\mathrm{N}_{2}$ adsorption-desorption isotherms at $-196{ }^{\circ} \mathrm{C}$, using a Quantachrome Autosorb-IQ apparatus. The average particle size and size distribution of the samples were investigated by transmission electron microscopy (TEM), using a Philips CM200 apparatus operated at $120 \mathrm{kV}$. Powder samples were sonicated in ethanol, and dispersed on copper grids. Elemental analysis was performed by ICP-AES, using a Perkin-Elmer Op- tima 2000 DV apparatus.

\subsection{Catalytic reaction tests}

The catalyst was reduced at $200{ }^{\circ} \mathrm{C}$ for $1.5 \mathrm{~h}$ under an atmosphere consisting of $\mathrm{Ar}: \mathrm{H}_{2}=2: 1$. The freshly reduced catalyst $(0.05 \mathrm{~g})$ was mixed with BYD (0.568 g) and 1,2-propylene glycol (an internal standard required for gas chromatography analysis) in $10 \mathrm{~mL}$ of $\mathrm{H}_{2} \mathrm{O}$. The mixture was transferred into a $50 \mathrm{~mL}$ batch reactor. The reactor was flushed with $\mathrm{H}_{2}$ three times, and catalytic hydrogenation was then carried out at a given $\mathrm{H}_{2}$ pressure and temperature. A blank test was performed following a conventional catalytic test procedure at 120 ${ }^{\circ} \mathrm{C}$ and $p\left(\mathrm{H}_{2}\right)=2 \mathrm{MPa}$, using pure ZIF-8 as the catalyst. Less than $2 \%$ conversion was obtained, indicating that ZIF-8 was inactive for the hydrogenation of BYD.

\section{Results and discussion}

\subsection{Characterization of Pt@ZIF-8}

A mild room temperature procedure was used to synthesize ZIF-8, which ensured that the structure of the Pt nano-sol was preserved. XRD patterns of ZIF-8 and Pt@ZIF-8 prepared by the one-step synthesis are shown in Fig. 2(a). The XRD patterns show that introducing the Pt nano-sol had negligible effect on the formation of ZIF-8. Both ZIF-8 and Pt@ZIF-8 exhibited very high crystallinity. The characteristic diffraction peaks of $\mathrm{Pt}$ could not be detected, because of the low Pt loading and high crystallinity of ZIF-8. $\mathrm{N}_{2}$ adsorption measurements of ZIF-8 and Pt@ZIF-8 are shown in Fig. 2(b). Type I isotherms were observed for both ZIF-8 and Pt@ZIF-8, according to IUPAC classifications. High surface areas of $1786 \mathrm{~m}^{2} / \mathrm{g}$ for ZIF-8 and 1747 $\mathrm{m}^{2} / \mathrm{g}$ for Pt@ZIF-8 were observed, along with narrow pore size distributions of 1-2 $\mathrm{nm}$. This indicated that the pore structure remained intact after loading with $\mathrm{Pt}$.

TEM images of the Pt NPs and Pt@ZIF-8 are shown in Fig. 3. The ZIF-8 framework was well crystallized. It had a smooth surface, and consisted of particles of about 100-200 nm in size. No additional impurities were observed in the TEM images, in agreement with the XRD results. The TEM images show that the Pt nano-sol exhibited very little change after being encapsulated in the ZIF-8 crystals. Pt NPs of size of 1-2 nm were randomly dispersed throughout the ZIF-8 support.

\subsection{Hydrogenation of BYD over the Pt@ZIF-8 catalyst}

The performance of Pt@ZIF-8 as a catalyst was tested in a<smiles>O=C([O-])C[14C](=O)[O-]</smiles>
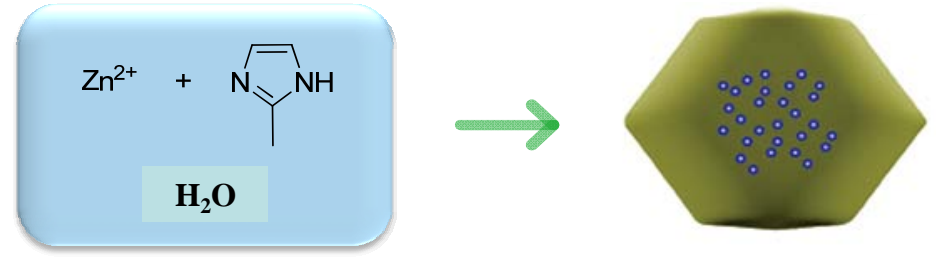

Fig. 1. Procedure for preparing Pt@ZIF-8. 

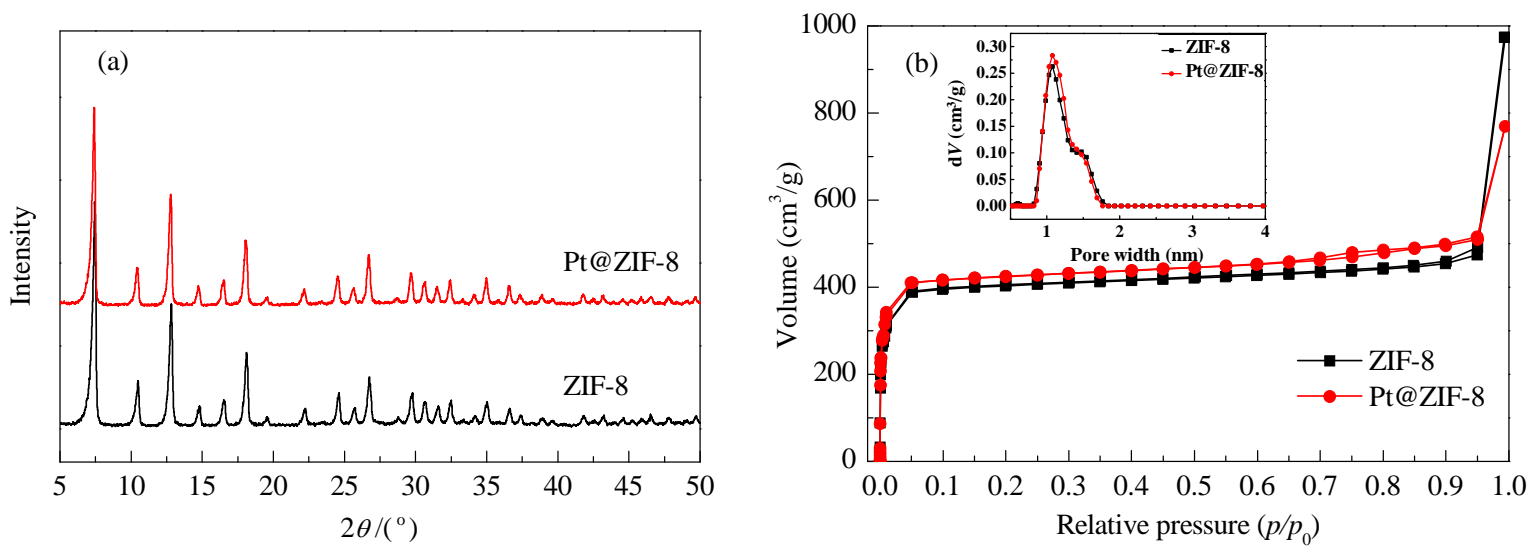

Fig. 2. XRD patterns (a) and $\mathrm{N}_{2}$ adsorption measurements (b) of ZIF-8 and Pt@ZIF-8.
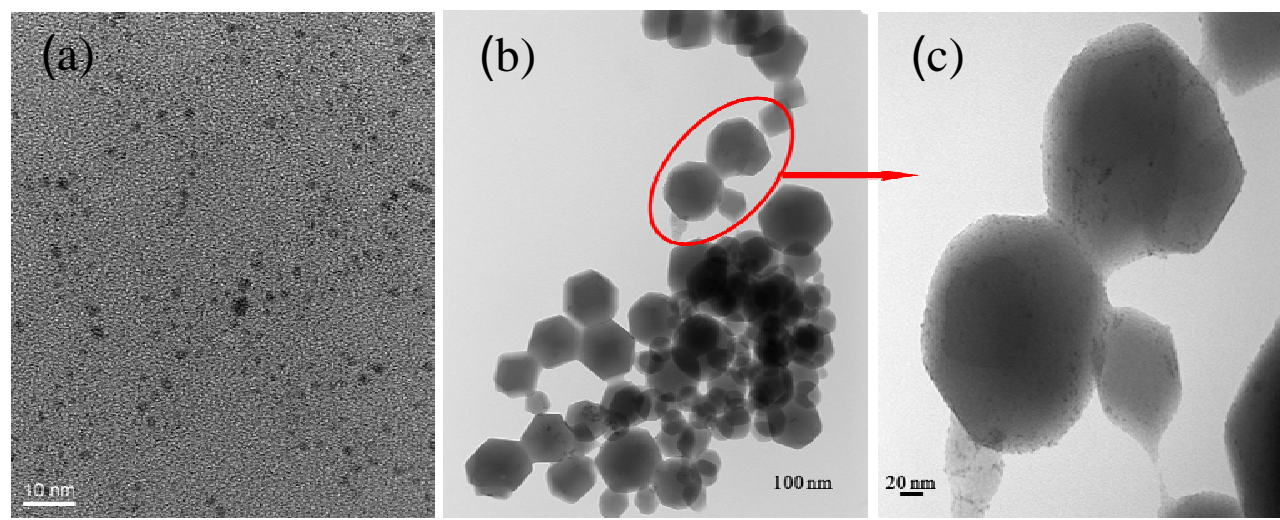

Fig. 3. TEM images of Pt nanoparticles (a) and Pt@ZIF-8 (b, c) via one-step method.

batch reactor, using $\mathrm{H}_{2} \mathrm{O}$ as a solvent. The general hydrogenation pathways of BYD are shown in Scheme 1. BYD can be easily and completely hydrogenated to BDO by monometallic $\mathrm{Pd}$ or $\mathrm{Pt}$ catalysts. The selectivity to mono-ene products can be suppressed by poisoning with bismuth, sulfur adatoms, lead, and Ag [4,9,23-25]. However, these catalytic systems usually provide high selectivity to partially hydrogenated products, as well posing a hazard because of their toxicity. It would advanta- geous if a high partial hydrogenation selectivity could be obtained without using these additives.

When the reaction temperature was $50^{\circ} \mathrm{C}$, a low BYD conversion of 10\% was obtained when using Pt@ZIF-8 as a catalyst under $\mathrm{a}_{2}$ pressure of $3 \mathrm{MPa}$ for $4 \mathrm{~h}$. The BYD conversion significantly increased with increasing temperature, and complete transformation was achieved at $120^{\circ} \mathrm{C}$. Higher temperatures often lead to the further hydrogenation of BED to BDO.

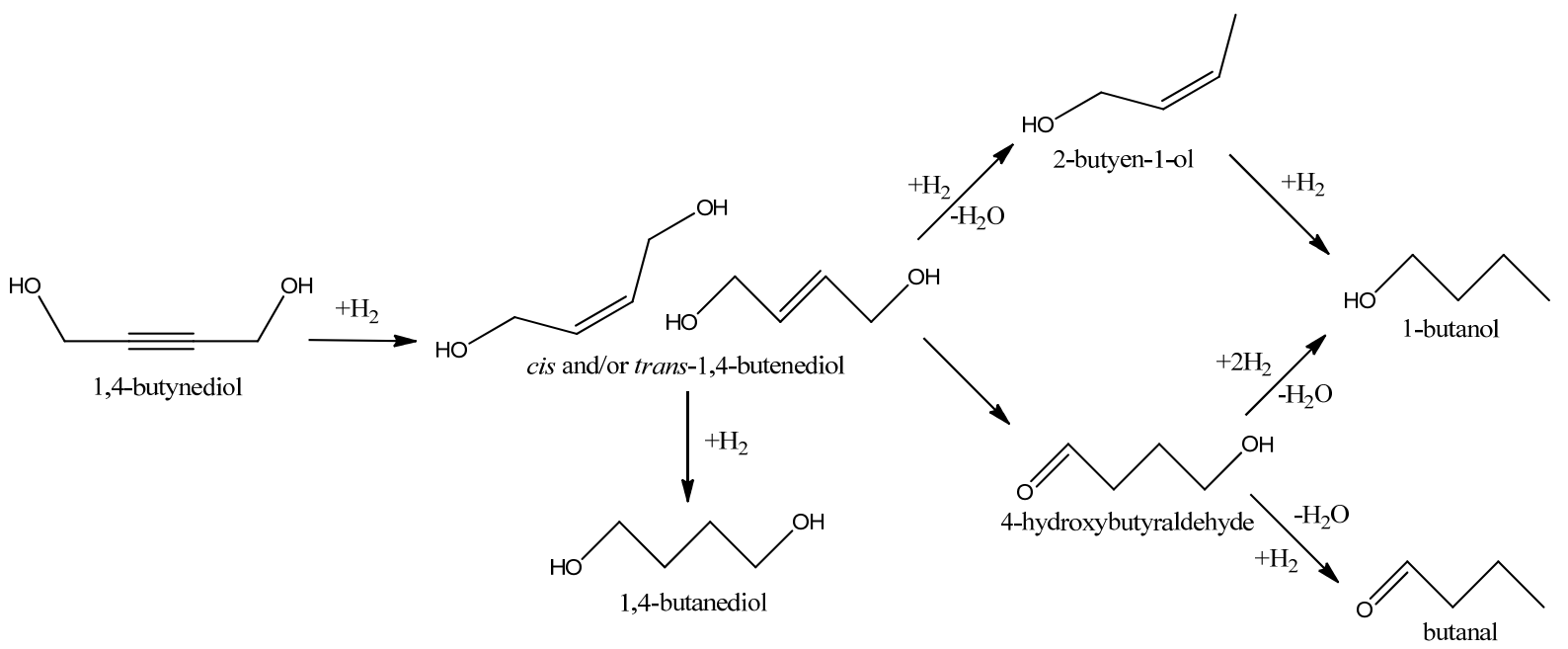

Scheme 1. Reaction pathway for the hydrogenation of BYD. 

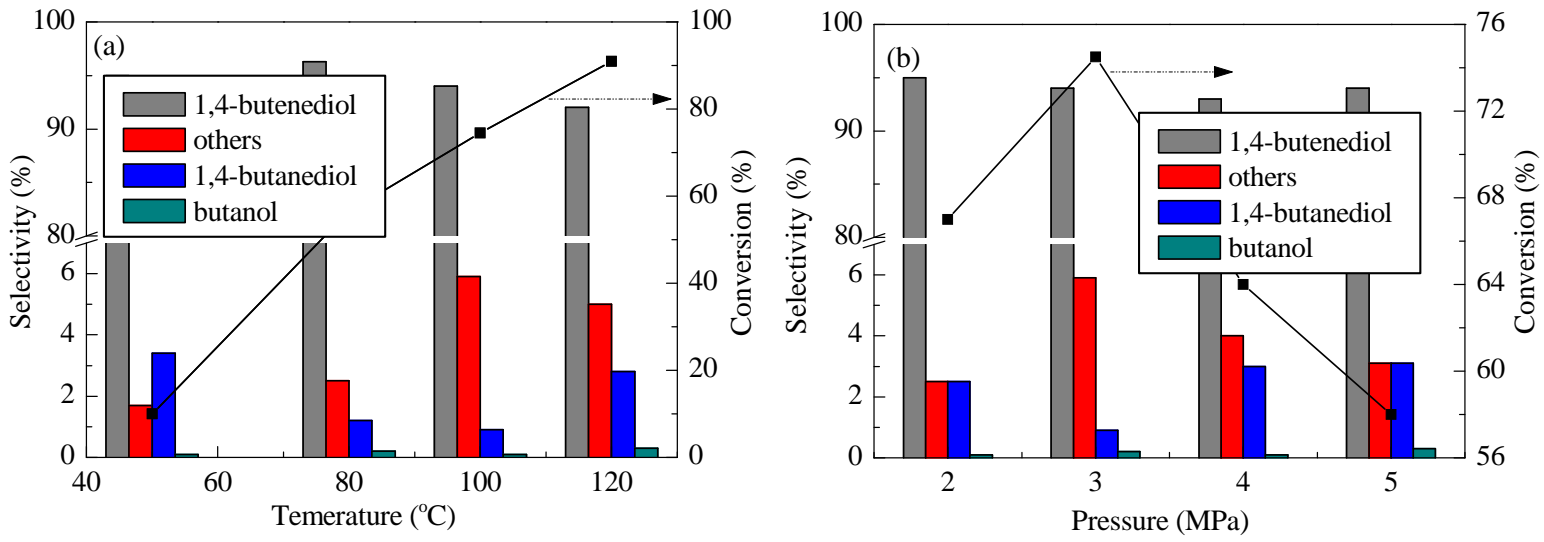

Fig. 4. Hydrogenation of BYD over Pt@ZIF-8 catalyst at different temperatures (a) and pressure (b).
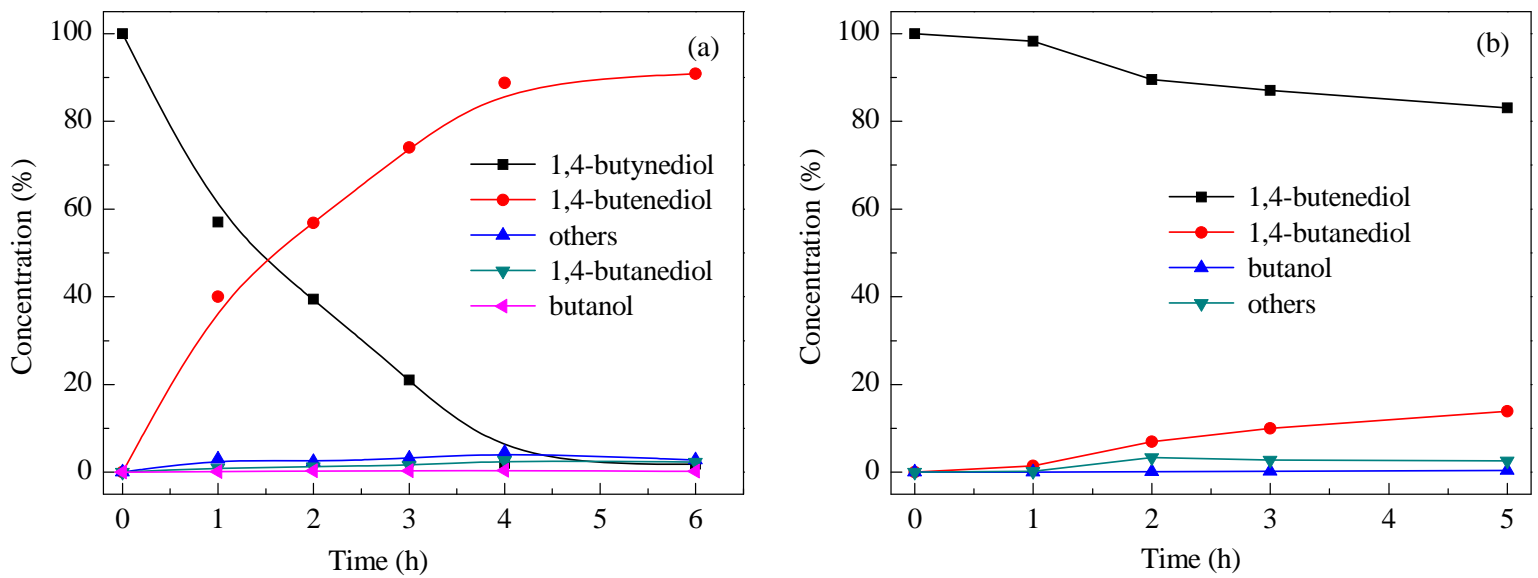

Fig. 5. Kinetics for hydrogenation of BYD (a) and BED (b) by Pt@ZIF-8.

However, a high BED selectivity ( $>92 \%$ ) was observed in the current study, regardless of the BYD conversion. The influence of temperature is shown in Fig. 4(a).

The pressure also affects the activity (Fig. 4(b)), and a decrease in conversion was anticipated at lower pressure. However, an excessively high pressure was also found to decrease the activity of the catalyst. This was attributed to the high internal surface area and the presence of metal cation sites in ZIF-8, which facilitated hydrogen adsorption. These properties mean that ZIF-8 supported Pt materials are promising candidates for hydrogen storage [26]. $\mathrm{H}_{2}$ pressure of over $3 \mathrm{MPa}$ resulted in increased adsorption of $\mathrm{H}_{2}$ molecules into the micropores of ZIF-8, which limited the ability of the BYD substrate to reach Pt sites encapsulated within the ZIF-8 framework. The selectivity to BED was consistently high at approximately $95 \%$, under various $\mathrm{H}_{2}$ pressure.

Kinetic data for the hydrogenation of BYD over 1 wt $\%$ Pt@ZIF-8 at $120^{\circ} \mathrm{C}$ and $3 \mathrm{MPa}$ of $\mathrm{H}_{2}$ pressure is shown in Fig. 5(a). Analysis of kinetic data can yield information about the interaction between structural properties and catalytic activity. Within the first $4 \mathrm{~h}$, the BYD concentration decreased linearly with increasing reaction time, confirming the zero order kinetics with respect to BYD. This observation was consistent with previous results of the hydrogenation of BYD over noble metals
[27]. At low reaction time (i.e. lower conversions), the hydrogenation of BYD primarily produced BED. The selectivity to BED was approximately $94 \%$ after $4 \mathrm{~h}$ of reaction time. BYD was almost completely converted within $4 \mathrm{~h}$, and high selectivity was maintained during the entire reaction process. A further $2 \mathrm{~h}$ of reaction time after the complete consumption of BYD yielded no obvious hydrogenation to cis-BED or isomerization. The selectivity to BED remained high (93\%) after $6 \mathrm{~h}$ of reaction, indicating that the reaction stopped after the first hydrogenation. The Pt@ZIF-8 catalyst in the hydrogenation of BYD in aqueous solution gave selectivity towards BED of up to $94 \%$ at conversions of up to $100 \%$. This was further confirmed by kinetic data for BED hydrogenation performed under the same conditions, as shown in Fig. 5(b). Less than 20\% of BED was converted to BDO after $5 \mathrm{~h}$, and no side products were observed. In comparison, a conventional Pt/C catalyst exhibited poor selectivity for BED $(<60 \%)$, under the same condition. The BED target product was also readily further hydrogenated to BDO, after the BYD substrate had been completely consumed [28]. These results suggested that the selectivity of the Pt@ZIF-8 catalyst resulted from its structural properties, rather than the reaction kinetics.

One possible reason for the high partial hydrogenation selectivity may have been the inhibiting effect from the protective 

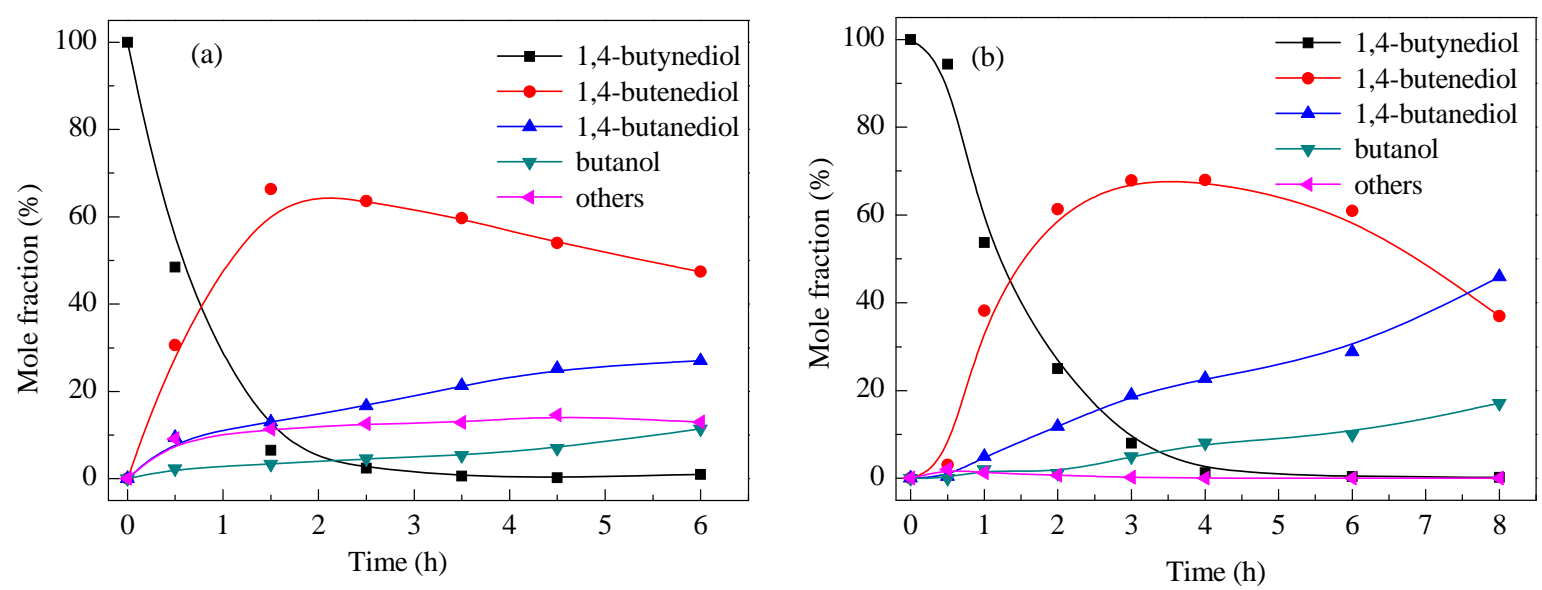

Fig. 6. Kinetics for hydrogenation of BYD over Pt nano-sol (a) and Pt@SBA-15 (b).

agent around the Pt NPs. This hypothesis can be verified by testing the catalytic performance of the Pt nano-sol, and the result is shown in Fig. 6(a). The acetate-protected Pt nano-sol exhibited a higher activity, requiring only $2 \mathrm{~h}$ to fully convert BYD. This may have resulted from the better contact between the Pt nano-sol and reactants, in the absence of the ZIF-8 support. The highest selectivity to BED (68\%) was obtained at 1.5 $\mathrm{h}$, and further hydrogenation and isomerization occurred as the reaction continued. Similar catalytic performance was observed when the ZIF-8 support was replaced with SBA-15, as shown in Fig. 6(b). Good selectivity was not observed in the absence of the ZIF-8 support, indicating that the favorable hydrogenation properties of Pt@ZIF-8 resulted from the role of ZIF-8. Zn- and N-containing organic ligands contained within the ZIF-8 structure are a common poison. Metal and organic inhibitors were also present to adjust the selectivity of the catalyst for the hydrogenation of BYD. The narrow pore diameter of ZIF-8 may also have suppressed isomerization.

\subsection{Recyclability of Pt@ZIF-8 catalyst for BYD hydrogenation}

The Pt@ZIF-8 catalyst could be reused without reactivation treatment, except requiring washing twice with $\mathrm{H}_{2} \mathrm{O}$. The recyclability of $1.0 \mathrm{wt} \%$ Pt@ZIF-8 at $120{ }^{\circ} \mathrm{C}$ and $p\left(\mathrm{H}_{2}\right)=3 \mathrm{MPa}$ is shown in Fig. 7(a). The kinetic data for BYD hydrogenation in Fig. 5(a) showed that BYD was fully converted in approximately 4 h. Thus, the reaction data in Fig. 7(a) was collected after 4 h. The sample exhibited reproducible performance over five runs, sustaining very good conversion of BYD (>91\%) and excellent selectivity for BED ( $>92 \%)$.

The XRD patterns of Pt@ZIF-8 before and after reaction are shown in Fig. 7(b). No obvious differences were observed between the patterns of fresh Pt@ZIF-8 and that after two reaction cycles, indicating that the ZIF-8 structure remained intact. The characteristic XRD peaks of ZnO began to emerge after four reaction cycles, indicating the decomposition of ZIF-8. The characteristic XRD peaks of ZIF-8 completely disappeared after five reaction cycles, indicating complete decomposition of the support at the high reaction temperature. The residual XRD peaks were consistent with $\mathrm{ZnO}$. BET results showed that the specific surface area decreased from 1747 to $40 \mathrm{~m}^{2} / \mathrm{g}$, over the five reaction cycles. The metal composition remained largely unchanged, at 21.3\% and 19.8\% for fresh Pt@ZIF-8 and that subjected to five reaction cycles. This indicated that the high surface area and narrow pore dimeter of ZIF-8 were not the main reasons for the high selectivity of the Pt@ZIF-8 catalyst for BED. ZnO was obtained by calcining ZIF-8 in air at $500{ }^{\circ} \mathrm{C}$ for $3 \mathrm{~h}$. The $\mathrm{Pt} / \mathrm{ZnO}$ catalyst was prepared by adding $\mathrm{ZnO}$ to the
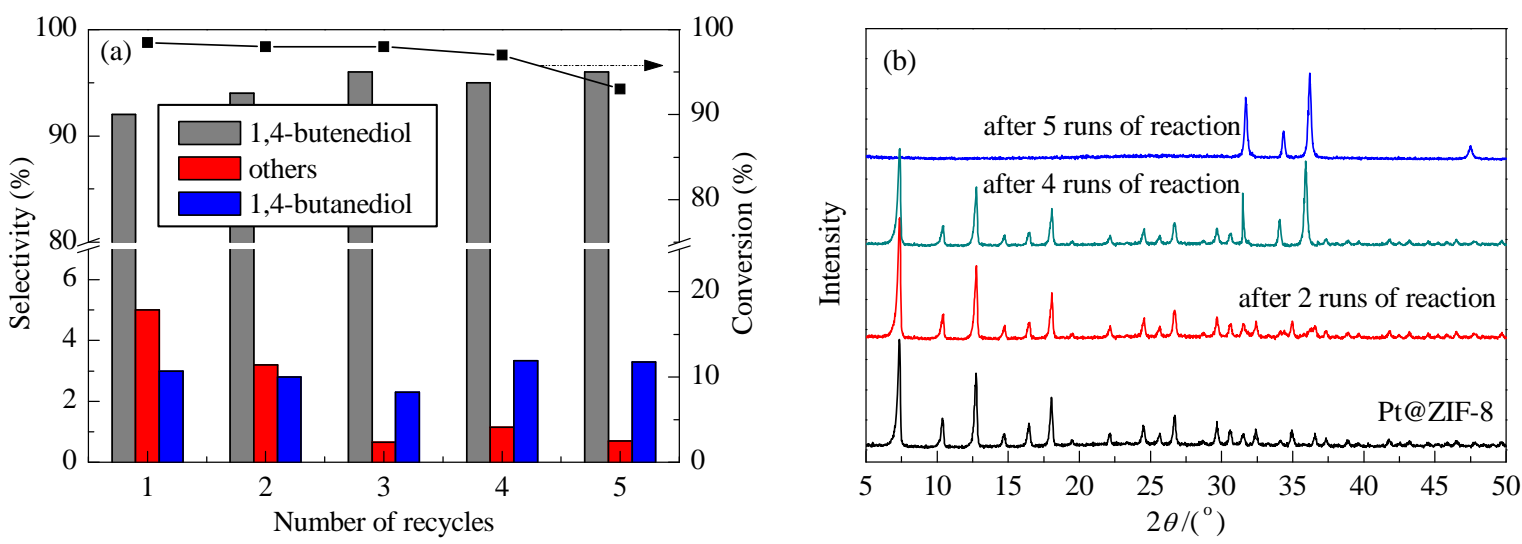

Fig. 7. Recyclability (a) and XRD patterns (b) of Pt@ZIF-8 before and after 4 h reaction cycles. 
Pt colloid. Dilute hydrochloric acid was then added to lower the $\mathrm{pH}$ to $<3$. This in turn lowered the concentration of the glycolate colloid stabilizer. The kinetics for the hydrogenation of BYD by the Pt/ZnO catalyst are shown for comparison. The Pt/ZnO catalyst exhibited poor selectivity for BED $(<65 \%)$. After four reaction cycles, the crystal structure of ZIF-8 began to degrade, and the 2-methylimidazole ligand on ZIF-8 began to partially decompose and adsorb to the Pt surface, which affected the catalysts performance. These results showed that nitrogen-containing organic ligands can play an important role in the partial hydrogenation. A possible reason for the good reusability of the catalyst even after ZIF-8 decomposition was that most of the Pt nano-sol was located on the outer surface of ZIF-8.

\section{Conclusions}

We prepared a catalyst containing Pt supported on ZIF-8, via a rapid dynamic crystallization method at room temperature. The Pt@ZIF-8 catalyst exhibited enhanced selectivity for 1,4-butenediol in the hydrogenation of 1,4-butynediol, because of the role of $\mathrm{Zn}^{2+}$ and N-containing organic ligands in ZIF-8. The high activity of Pt@ZIF-8 resulted from the catalysts with high specific surface area and well-dispersed Pt NPs. Pt@ZIF-8 exhibited excellent performance and reusability, although the ZIF-8 structure began to degrade after more than two reaction recycles.

\section{References}

[1] A. Molnar, A. Sarkany, M. Varga, J. Mol. Catal. A, 2001, 173, 185221.

[2] M. Crespo-Quesada, F. Cardenas-Lizana, A. Dessimoz, L. Kiwi-Minsker, ACS Catal., 2012, 2, 1773-1786.

[3] J. M. Winterbottom, H. Marwan, J. Viladevall, S. Raymarhasay, Stud. Surf. Sci. Catal., 1997, 108, 59-66.

[4] R. V. Chaudhari, R. Jaganathan, D. S. Kolhe, G. Emig, H. Hofmann, Appl. Catal., 1987, 23, 141-159.

[5] M. M. Telkar, C. V. Rode, V. H. Rane, R. Jagernathan, R. V.
Chaudhari, Appl. Catal. A, 2001, 216, 13-22.

[6] H. Lindlar, Helvet. Chim. Acta., 1952, 35, 446-450.

[7] A. Bruehwiler, N. Semagina, M. Grasemann, A. Renken, L. Kiwi-Minsker, A. Saaler, H. Lehmann, W. Bonrath, F. Roessler, Ind. Eng. Chem. Res., 2008, 47, 6862-6869.

[8] R. V. Chaudhari, M. G. Parande, P. A. Ramachandran, P. H. Brahme, H. G. Vadgaonkar, R. Jaganathan, AIChE J., 1985, 31, 1891-1903.

[9] G. Bollger, R. Boer, W. Wache, H. Gratze, W. Koerning, DE Patent 2451929, 1976.

[10] J. Wood, L. Bodenes, J. Bennett, K. Deplanche, L. E. Macaskie Ind. Eng. Chem. Res., 2010, 49, 980-988.

[11] M. M. Zhang, J. C. Guan, B. S. Zhang, D. S. Su, C. T. Williams, C. H. Liang, Catal. Lett., 2012, 142, 313-318.

[12] M. Sabo, A. Henschel, H. Frode, E. Klemm, S. Kaskel, J. Mater. Chem., 2007, 17, 3827-3832.

[13] X. F. Zhang, F. X. Llabres, I. Xamena, A. Corma, J. Catal,, 2009, 265, 155-160.

[14] G. Lu, S. Z. Li, Z. Guo, O. K. Farha, B. G. Hauser, X. Y. Qi, Y. Wang, X. Wang, S. Han, X. Liu, J. S. DuChene, H. Zhang, Q. Zhang, X. Chen, J. Ma, S. C. Joachim Loo, D. W. Wei, Y. Yang, J. T. Hupp, F. Huo, Nature Chem., 2012, 4, 310-316.

[15] D. Farrusseng, S. Aguado, C. Pinel, Angew. Chem. Int. Ed., 2009, 48, $7502-7513$.

[16] C. J. Stephenson, J. T. Hupp, O. K. Farha, Inorg. Chem. Front., 2015, $2,448-452$.

[17] X. Q. Jia, S. H. Wang, Y. Fan, J. Catal., 2015, 327, 54-57.

[18] Y. Zhang, A. Thomas, M. Antonietti, X. C. Wang, J. Am. Chem. Soc., 2009, 131, 50-51.

[19] Y. Wang, J. Yao, H. R. Li, D. S. Su, M. Antonietti, J. Am. Chem. Soc., 2011, 133, 2362-2365.

[20] M. M. Zhang, Y. B. Yang, C. Li, Q. Liu, C. T. Williams, C. H. Liang, Catal. Sci. Technol., 2014, 4, 329-332.

[21] C. Li, Z. F. Shao, M. Pang, C. T. Williams, C. H. Liang, Catal. Today, 2012, 186, 69-75.

[22] C. Li, Z. F. Shao, M. Pang, C. T. Williams, C. H. Liang, Ind. Eng. Chem. Res., 2012, 51, 4934-4941.

[23] J. M. Winterbottom, H. Marwan, J. Viladevall, S. Sharma, S. Raymahasay, Stud. Surf. Sci. Catal., 1997, 108, 59-66.

[24] V. I. Rode, P. R. Tayade, J. M. Nadgeri, R. Jaganathan, R. V. Chaudhair, Org. Process Res. Dev., 2006, 10, 278-284.

[25] J. A. Isaeva, O. P. Tkachenko, E. V. Afonina, L. M. Kozlova, G. I. Kapustin, W. Grünert, S. E. Soloveva, I. S. Antipin, L. M. Kustov,

\section{Graphical Abstract}

Chin. J. Catal., 2016, 37: 1555-1561 doi: 10.1016/S1872-2067(16)62497-X

\section{One-step synthesis of Pt@ZIF-8 catalyst for the selective hydrogenation of 1,4-butynediol to 1,4-butenediol}

Chuang Li, Mingming Zhang, Xin Di, Dongdong Yin, Wenzhen Li, Changhai Liang*

Dalian University of Technology, China;

Iowa State University, USA

Pt@ZIF-8 was synthesized by a one-step method, and applied in the hydrogenation of 2-butyne-1,4-diol to 2-butene-1,4-diol, exhibiting high activity, selectivity, and absolute reusability.

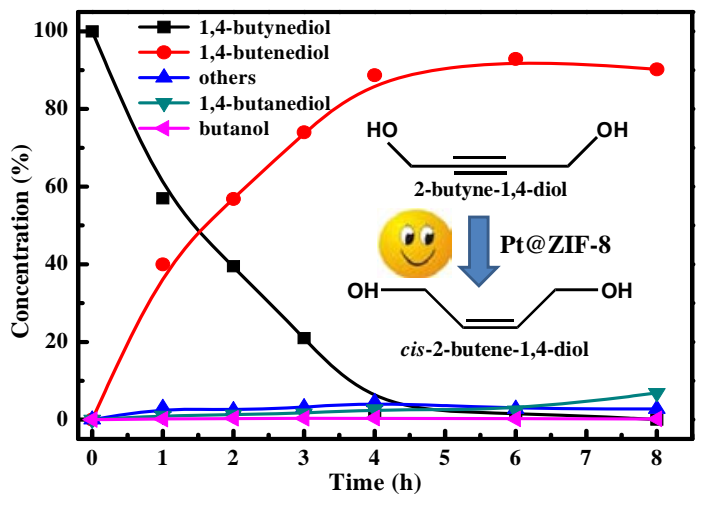


Microporous Mesoporous Mater., 2013, 166, 167-175.

[26] K. Sumida, S. Horike, S. S. Kaye, Z. R. Herm, W. L. Queen, C. M. Brown, F. Grandjean, G. J. Long, A. Dailly, J. R. Long, Chem. Sci., 2010, 1, 184-191.
[27] E. Joannet, C. Horny, L. Kiwi-Minsker, A. Renken, Chem. Eng. Sci., 2002, 57, 3453-3460.

J. A. Bennett, G. A. Attard, K. Deplanche, M. Casadesus, S. E. Huxter, L. E. Macaskie, J. Wood, ACS Catal., 2012, 2, 504-511.

\title{
一步法合成 Pt@ZIF-8 及其在 1,4-丁炔二醇选择加氢中的应用
}

\author{
李 闯 ${ }^{\mathrm{a}}$, 张明明 ${ }^{\mathrm{a}}$, 邸 金拿, 殷东东 ${ }^{\mathrm{a}}$, 李文震 ${ }^{\mathrm{b}}$, 梁长海, ${ }^{\mathrm{a},}$ \\ a 大连理工大学化工学院先进材料和催化工程实验室, 辽宁大连 116024 \\ b爱荷华州立大学生物质可再生能源实验室, 美国爱荷华州 50011
}

摘要: 1,4-丁炔二醇 (BYD) 部分加氢生成 1,4-丁烯二醇 (BED), BED 进一步加氢生成 1,4-丁二醇 (BDO). 此外, BYD, BED 和 $\mathrm{BDO}$ 还会发生脱水反应生成单醇类产物. 工业上 BYD 加氢反应主要用于生产 BDO. 由于传统的单金属加氢催化剂很 难控制反应的加氢程度, 因此一般通过提高反应温度和压力使 BYD 尽量转化为完全加氢产物 BDO, 以减少部分加氢产物 BED对最终产品收率的影响. 部分加氢产物 BED 在精细化工领域也具有重要的应用, 所以选择合适的催化剂和反应条件 来提高部分加氢产物 BED 的选择性具有重要的理论意义和潜在应用价值. 文献中常采用 $\mathrm{Zn}$ 、微生物等活性抑制剂来降低 贵金属催化剂的加氢活性. 这些方法往往比较复杂, 所使用的添加剂不仅存在毒性和污染产物, 还会增加成本. 这些方法 得到的催化材料虽然可以提高烯醇的选择性, 但是仍需要严格控制反应条件才能得到较高收率的部分加氢产物. 本文基 于 MOFs 材料独特的结构和性质, 探索了 MOFs 负载型贵金属催化剂在选择加氢反应中的催化性能.

首先制备了一种羧酸根保护的 Pt 纳米溶胶, 并以水为溶剂, 增加 2-甲基咪唑的加入量, 实现了室温下 ZIF-8 晶体的快 速生成. 在室温合成 ZIF-8 的过程中加入羧酸根保护的 Pt 纳米溶胶, 通过羧酸根与 ZIF-8 之间存在的化学吸附力, 实现 ZIF-8 对 Pt 纳米粒子的包覆. 羧酸根不仅可以稳定溶液中的纳米粒子, 同时还起着 “桥梁” 的作用. 羧酸根中的 C=O 基团 与 ZIF-8 中的 Zn 原子或有机骨架之间弱的配位作用, 增加了纳米粒子和 ZIF-8 之间的亲和力, 实现了金属纳米粒子被 ZIF-8 包围. Pt 纳米粒子的引入对 ZIF-8 的形成也没有影响, 得到的 Pt@ZIF-8 材料拥有良好的晶体结构和高的比表面积.

采用 XRD、 $\mathrm{N}_{2}$ 吸附和TEM 等表征揭示了 Pt@ZIF-8 的结构特点, 并研究了其在水相 1,4-丁炔二醇加氢反应中的催化性 能. 结果显示, 该材料不仅具有很高的活性, 还具有突出的部分加氢选择性. 在 5 次循环反应中, BYD 转化率没有明显变 化, 说明催化剂在反应过程中活性没有降低. 在多次反应之后, 反应产物的分布也没有发生明显变化, 1,4-丁烯二醇选择性 在 5 次反应中都保持在 $94 \%$ 以上. 结构表征结果则显示, 在 4 次循环使用之后, 催化剂的结构已经遭到破坏; 5 次循环使 用之后, 催化剂的 XRD 谱图中 ZIF-8 的特征衍射峰完全消失. 其余谱峰为 ZnO 特征衍射峰, 说明由于反应温度较高, 催化 剂在多次反应之后其载体 ZIF-8 发生了分解. 循环寿命实验说明, ZIF-8 中 Zn 离子和含氮有机骨架的抑制作用是导致 1,4丁烯二醇高选择性的重要原因. ZIF-8 的分解虽然会使孔道塌陷, 但是结构中的 Zn 和含氮的有机骨架组成依然存在, 仍然 可以达到抑制烯醇进一步加氢的效果, 并且 Pt 纳米溶胶主要存在于外表面, 所以催化剂的活性和选择性没有发生明显变 化.

关键词: 铂溶胶; ZIF-8; 一步合成; 1,4-丁炔二醇; 选择加氢

收稿日期: 2016-05-06. 接受日期: 2016-06-30. 出版日期: 2016-09-05.

*通讯联系人. 电话/传真: (0411)84986353; 电子信箱: changhai@dlut.edu.cn

基金来源：国家自然科学基金 (21573031, 21428301); 中央高校基本科研业务费专项资金 (DUT15ZD106, DUT15RC(4)09).

本文的英文电子版由Elsevier出版社在ScienceDirect上出版(http://www.sciencedirect.com/science/journal/18722067). 